\title{
A systematic review of 3D printing in chemistry education : analysis of earlier research and educational use through technological pedagogical content knowledge framework
}

\section{Pernaa, Johannes}

\section{0}

Pernaa , J \& Wiedmer , S 2020 , ' A systematic review of 3D printing in chemistry education : analysis of earlier research and educational use through technological pedagogical content knowledge framework ' , Chemistry Teacher International , vol. 2 , no. 2 . https://doi.org/10.1515/cti-2019-0005

http://hdl.handle.net/10138/327070

https://doi.org/10.1515/cti-2019-0005

cc_by_nc_nd

publishedVersion

Downloaded from Helda, University of Helsinki institutional repository.

This is an electronic reprint of the original article.

This reprint may differ from the original in pagination and typographic detail.

Please cite the original version. 


\title{
A systematic review of 3D printing in chemistry education - analysis of earlier research and educational use through technological pedagogical content knowledge framework
}

\author{
${ }^{1}$ University of Helsinki, Department of Chemistry, The Unit of Chemistry Teacher Education, Helsinki, Finland, Tel. No. \\ +358503480567, E-mail: johannes.pernaa@helsinki.fi. https://orcid.org/0000-0003-1735-5767. \\ ${ }^{2}$ University of Helsinki, Department of Chemistry, Helsinki, Finland
}

\begin{abstract}
:
The focus of this systematic literature analysis is to provide a comprehensive review of earlier research on the utilisation of 3D printers in chemistry education. The objective is to offer research-based knowledge for developing chemistry education through following research questions: what kind of work has been done in the field of 3D printing in chemistry education; what kind of design strategies have been implemented; how 3D printing has been used in chemistry education research. The data consists of 47 peer-reviewed articles which were analysed via qualitative content analysis using a technological pedagogical content knowledge framework. Theoretical framework was selected because integrating 3D printing in chemistry education requires knowledge of chemistry, technology, and most importantly, pedagogy. Our research indicates that integrating 3D printing begins by analysing current challenges which are reasoned via pedagogical or technological content knowledge-based arguments. 3D printing was used for producing solutions (e.g. physical models) that support working with found challenges. In chemistry education research, 3D printing has mainly been used for printing research instruments; few studies have investigated its effect on learning or students' perceptions towards it. There is a great need for comprehensive student-centred pedagogical models for the use of 3D printing in chemistry education.
\end{abstract}

Keywords: 3D printing, laboratory, safety, technology, TPACK

DOI: 10.1515/cti-2019-0005

\section{Introduction}

Additive manufacturing, commonly known as 3D printing, refers to technologies that build 3D objects by adding material layer by layer. Added material can be, for example, plastic or metal; the former is the most used in chemistry education (Bharti \& Singh, 2017). Additive manufacturing has many advantages compared to traditional processes. Firstly, in many cases it is easier to produce complex artefacts additively than subtractive (e.g. CNC machining) (Jamie, 2018; Lolur \& Dawes, 2014). Secondly - and most importantly - the waste of raw material is minimal, supporting environmentally friendly and sustainable chemistry thinking (Andraos \& Dicks, 2012).

Additive manufacturing is a rapidly growing field. Although currently it is only a marginal part of the entire manufacturing industry, it is nevertheless considered a common production method alongside traditional methods (Long, 2018). It is already an essential technique for digital manufacturing and home fabrication, and the general consensus is that 3D printing will be one of the next major technological revolutions (Rayna \& Striukova, 2016).

According to Hart (2017a), fast growth has created a skill gap in additive manufacturing. The rising industry is struggling to find people skilled in 3D printing and is looking for support from the education sector. The additive manufacturing industry has a great need for experts; the education sector has the possibility and responsibility to respond to this demand (Hart, 2017a, Hart). This need has been recognized in schools, and enthusiastic teachers worldwide are developing pedagogical models on the integration of 3D printing in school curricula. At the same time, the price of 3D printers has decreased, enabling more schools to purchase the 
technology (Litts, 2015). Expectations are high - teachers using 3D printing have reported that it supports the development of multiple skills relevant for the $21^{\text {st }}$ century, such as 3D modelling, creativity, and important learning skills (e.g. critical thinking, problem-solving and self-directed learning) (Trust \& Maloy, 2017). Enthusiasm about 3D printing as an educational innovation is massive, however Nemorin and Selwyn (2017) argued that integrating 3D printing in a learning context is a challenging design task for the learning environment. Hence, it is important to understand how this new technology is being used in schools, and if it represents a new innovative form of education. According to their research, there were many cases where such new technology was used to support the traditional behaviourist way of teaching and learning. Nemorin and Selwyn (2017) research findings, however, conflict with the hopes that are set for educational 3D printing (Trust \& Maloy, 2017).

Nemorin and Selwyn (2017) suggest that the pedagogical use of 3D printing might change over time, after more teachers and students become familiar with the makerspace culture. It could change the working culture around 3D printing in formal education, and 3D printing could also serve as one model for informal out-ofschool learning. However, the cultural change will take time, yet the need for skilled additive manufacturers is immediate, making this topic of outmost importance in current chemistry education (Nemorin \& Selwyn, 2017).

It has been proposed that "3D printing offers nearly unlimited potential for chemical educators" (Davis, Jones, Thiel, \& Pauls, 2018). Although several articles have been published on this topic, the current state of research and pedagogical development remains unclear. The goal of the present article is to evaluate this potential via a comprehensive review of published literature on $3 \mathrm{D}$ printing. We approach this goal by analysing the type of publications that have been published, the reported motivation for 3D printing, and the type of learning environment design strategies that have been used. The analysis of strategies is carried out using a Technological Pedagogical Content Knowledge (TPACK) framework, which is widely used to understand the possibilities and challenges related to the pedagogical use of technology in general (Koehler, Mishra, \& Cain, 2013; Mishra \& Koehler, 2006). This review summarizes the current state of 3D printing in chemistry education, which in turn should enable the development of chemistry teacher education and research that comprehensively accounts for the earlier research done in this field.

\section{Technological pedagogical content knowledge}

TPACK is a widely adopted knowledge framework that illustrates the different types of knowledge that teachers need to master for the successful use of technology in their teaching (Koehler \& Mishra 2005; 2009; Mishra \& Koehler, 2006). Since its publication in 2005, there are over 900 published TPACK-related research articles (TPACK.org, 2018). It was originally developed to respond to the criticism concerning the lack of theoretical grounding for educational technology (Koehler \& Mishra, 2005). From historical perspective, TPACK is an iteration of Shulman's Pedagogical Content Knowledge (PCK) model (Shulman 1986; 1987), which emphasized the important interaction between pedagogical knowledge and content knowledge. PCK model was developed before the age of modern educational technology, which inspired Mishra and Koehler to redesign Shulman's ideas with the aim of explaining how teachers' understanding of how technology and PCK can interact, resulting in the successful integration of education and technology (Koehler \& Mishra, 2005; Mishra \& Koehler, 2006).

The TPACK framework consists of several knowledge domains (Figure 1). The three main components of teachers' knowledge are pedagogical knowledge (PK), content knowledge (CK), and technological knowledge (TK) (Koehler \& Mishra, 2005; Mishra \& Koehler, 2006). 


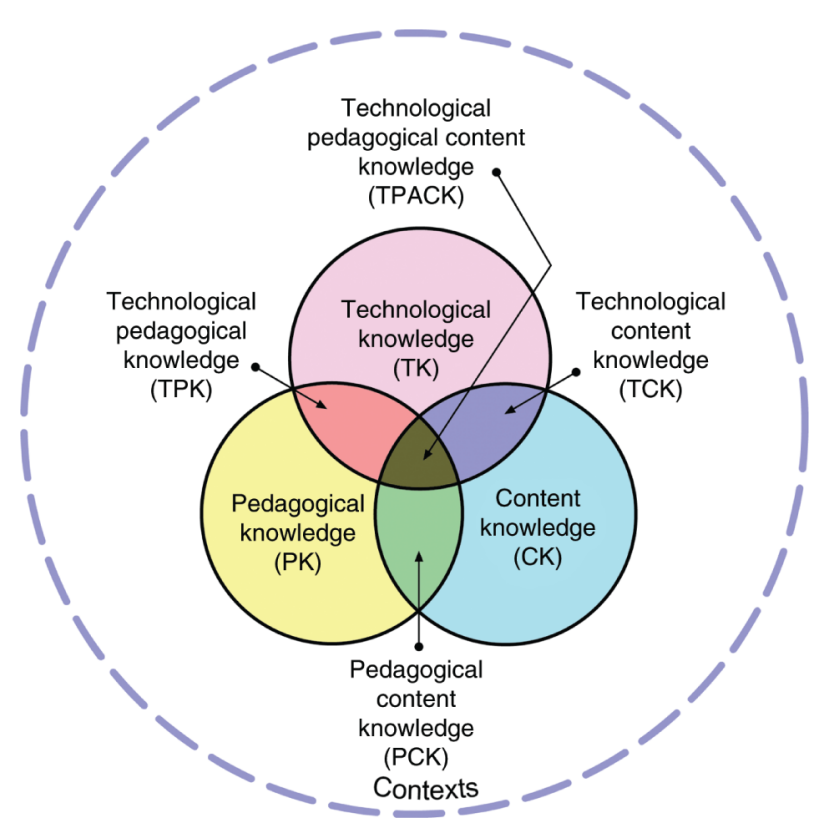

Figure 1: A model of the TPACK framework. Reproduced with permission of the publisher, @ 2012 by tpack.org.

- PK is the knowledge about teaching and learning in general (i.e. how students learn).

- CK is the knowledge about chemistry (i.e. concepts, theories, and research techniques).

- TK covers the knowledge about how to use technology (e.g. devices, software, communication tools) to support work and everyday life. TK must be constantly developed because of the rapid changes in information and communication technology (ICT) (Koehler \& Mishra, 2009; Koehler et al., 2013).

The interaction of these components forms three complex knowledge categories: pedagogical content knowledge (PCK), technological content knowledge (TCK), and technological pedagogical knowledge (TPK) (Koehler \& Mishra, 2005; Mishra \& Koehler, 2006).

- PCK is the knowledge about chemistry and its subject-specific learning (e.g. the ability to create learning material that accounts for prior knowledge and alternative conceptions).

- TCK is the understanding of how chemistry and chemistry learning can be supported via technology from a subject-specific point of view (e.g. microcomputer-based laboratories, molecular modelling or molecular level simulations).

- TPK is the understanding of the possibilities that technology can offer for learning. TPK does not have a subject-specific (CK) perspective (Koehler \& Mishra, 2009; Koehler et al., 2013).

TPACK is a knowledge domain that emerges from the interaction of content, pedagogy, and technology knowledge in the chosen context. It is a more versatile understanding of possibilities and challenges of ICT in teaching and learning than any other knowledge domain that explores these concepts individually (Koehler et al., 2013). For example, a teacher masters the chemistry topic (e.g. acids and bases), its history and current state of research (CK), knows about the chemistry educational research on the topic and uses it in designing teaching (PCK), knows how the topic can be visualized using computers (TCK), is familiar with the possibilities and limitations of visualisations in teaching (TPK), and understands how learning is supported from both general (PK) and chemistry learning perspectives (PCK).

In chemistry education research, some of the uses of TPACK include analysing pedagogical models on how simulations can be used in teaching (Khan, 2011), studying chemistry teachers' self-efficacy beliefs related to the use of certain technology and social media (Blonder et al., 2013; Blonder \& Rap, 2017), evaluating the effect of certain courses in pre-service teacher training (Çalik, Özsevgeç, Ebenezer, Artun, \& Küçük, 2014; Cetin-Dindar, Boz, Sonmez, \& Celep, 2018), and mapping teachers' use of ICT in classroom practices in order to design accurate in-service ICT training programs (Helppolainen \& Aksela, 2015).

According to Koehler et al. (2013), TPACK has been widely used in ICT-related learning environment designs. They evaluated 141 research articles and isolated three main approaches for developing TPACK, which are: 
1. PCK to TPACK: Teachers analyse their PCK and try to find technological solutions that match the subjectspecific needs.

2. TPK to TPACK: Teachers evaluate different technology solutions and try to use them to support learning of certain chemistry topics.

3. Simultaneous development of PCK and TPACK: Teachers develop their teaching via iterative projects, which enable insights in pedagogy, technology, content, and their interaction at the same time. (Koehler et al., 2013)

This context on how the TPACK framework is used was also applied in the current study. The three above mentioned approaches were used to evaluate the major TPACK design strategies implemented in earlier 3D printing literature. These are tightly connected with the other goal of this research, which was to analyse the motivation for applying 3D printing in chemistry education. The hypothesis was that adopting new technology has some educational objective that attempts to change the current situation.

TPACK model has also been criticized. E.g. Graham (2011) discusses that the diversity and inaccuracy of definitions for different knowledge components makes the model unclear and unpractical (see also Cox, 2008; Willermark, 2018 for more critical views). Even though the critics, the extensive use of TPACK and chemistry educational research examples makes us confident that TPACK is a suitable tool for systematically reviewing and understanding the previous work done in the field. This will support designing the future 3D printing research in chemistry education.

\section{Methods}

This research was executed as a systematic literature analysis, which was chosen because it is an appropriate strategy for achieving the goal of including all relevant articles in the analysis (Nightingale, 2009). The study was conducted by answering the following research questions derived from the research objectives:

- RQ1: What kind of work has been done in the field of 3D printing in chemistry education?

- RQ2: What kind of design strategies have been used in developing TPACK through integrating 3D printing in chemistry education?

- RQ3: How 3D printing has been used in chemistry education research?

Research data was selected via relevance sampling (Krippendorff, 2004, pp. 118-121). We included all relevant peer-reviewed articles discussing 3D printing in chemistry education. The data was gathered from the most established educational research article databases like DOAJ, ERIC, Google Scholar, and Scopus (Table 1). In total, 47 peer reviewed articles were retrieved in the information retrieval process (until March 25, 2019). Conference papers, book chapters, letters, etc. were excluded from the data because of the uncertainty of the peer-reviewing process.

Table 1: Databases, search phrases, and number of articles retrieved.

\begin{tabular}{|c|c|c|c|c|}
\hline Database & Search phrase & $\begin{array}{r}\text { All articles } \\
\text { found }\end{array}$ & $\begin{array}{r}\text { Relevant } \\
\text { articles }\end{array}$ & $\begin{array}{r}\text { Retrieval } \\
\text { date }\end{array}$ \\
\hline DOAJ & 3D AND printing AND chemistry AND education & 9 & 0 & $25 / 3 / 19$ \\
\hline ERIC & 3D AND printing AND chemistry ${ }^{\mathrm{a}}$ & 25 & 24 & $25 / 3 / 19$ \\
\hline Google scholar & “3D printing” AND “chemistry education”b & 124 & 15 & $25 / 3 / 19$ \\
\hline Scopus & $\begin{array}{l}\text { 3D AND printing AND chemistry AND education AND } \\
\text { (LIMIT-TO (SUBJAREA, “SOCI")) AND (LIMIT-TO } \\
\text { (SUBJAREA, “CHEM")) }\end{array}$ & 51 & 40 & $25 / 3 / 19$ \\
\hline
\end{tabular}

aThe ERIC database only includes educational research articles, hence the inclusion of "education" is not necessary.

bIn the Google Scholar information retrieval, we needed to use the exact search phrases for "3D printing" and "chemistry education" in order to narrow down the search results to a meaningful level. Without quotation marks, Scholar found over 64,000 results that were highly irrelevant from the education point of view.

RQ1 was answered via a general overview of the published literature. RQ2 and RQ3 were answered by analysing articles with qualitative content analysis, which is an analysis method that enables systematic and replicable literature analysis. We used two kinds of qualitative analysis methods, depending on the analysis 
needs. The first was a deductive theory-based approach (Krippendorff, 2004), which was applied in situations where we needed to analyse how different TPACK components (PCK, TCK or TPK) appeared in the design process. The other approach was an inductive content-based approach, which was used in cases where the goal was to derive new classifications from the literature.

In general, the analysis processes were carried out through the following steps (see comparison of inductive and deductive approaches in Table 2):

Table 2: Comparison of content-based and theory-based analysis processes and outcomes.

\begin{tabular}{lll}
\hline Analysis step & Theory-based analysis & Content-based analysis \\
\hline Theory-based main categories & PCK, TCK, TPK & - \\
Original expression & $\mathrm{x}$ & $\mathrm{x}$ \\
Reduction & $\mathrm{x}$ & $\mathrm{x}$ \\
Sub-categories & $\mathrm{x}$ & $\mathrm{x}$ \\
Outcome & Sub-categories assigned to the main & Content-derived classifications \\
& theory-based categories & \\
\hline
\end{tabular}

1. The research questions determined an analysis unit. For example, using the theory-based approach, we looked for expressions that matched the descriptions of PCK, TCK and TPK.

2. Original expressions were reduced into smaller phrases if they were too long.

3. Reduced phrases were classified into sub-categories.

4. Sub-categories were classified as either theory-based or assigned to new categories.

When suitable, reliability of the analysis was evaluated using Cohen's kappa inter-rater reliability test. Cohen's kappa is a statistic evaluation model that illustrates the degree of agreement among raters. A kappa value greater than 0.80 indicates a strong level of agreement (McHugh, 2012).

\section{Results}

\section{Overview of earlier work (RQ1)}

The total amount of articles published on 3D printing in the field of chemistry education was 47 . The majority of the academic discussion appeared in the Journal of Chemistry Education (37 articles). The first publication was in 2010; since then, the number of publications has increased steadily (Figure 2).

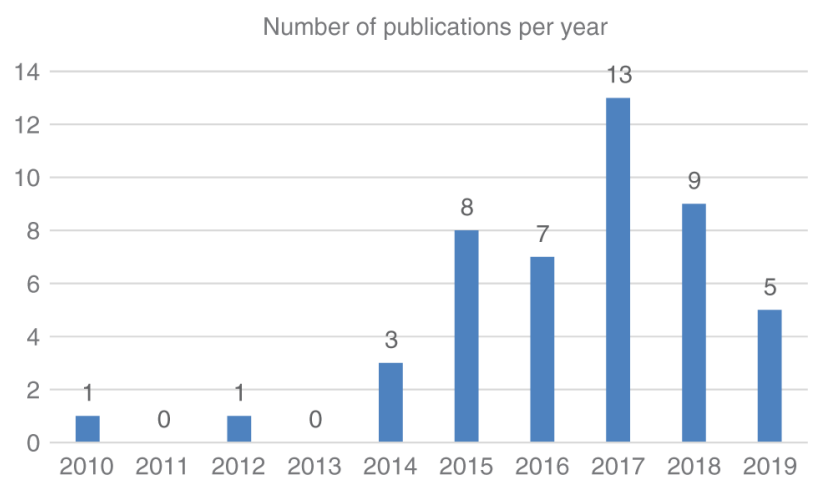

Figure 2: The number of 3D printing publications in chemistry education per year.

Ten of the 47 articles were classified as research articles, which were defined as articles that included some empirical section that studied, for example, students' perceptions or measured physical models' effect on learning. The remaining 37 articles focused on developing printing methodologies, analysing safety issues, developing pedagogical models and meaningful printing contexts (e.g. chemistry concepts and laboratory instruments) (see Table 3). Almost all of the articles discussed printing methodologies to some extent, but only eight articles 
focused exclusively on it. Presentation of suitable printing contexts for chemistry education was the biggest objective category identified from earlier publications. Altogether, 28 articles focused on describing which chemistry topics or laboratory instruments could benefit from 3D printing. All articles analysed in the research, as well as their full categorisation, are listed in Appendix 1.

Table 3: Classification of 3D printing articles.

\begin{tabular}{lrr}
\hline Article category & Frequency & Percentage \\
\hline Laboratory & 10 & $21.3 \%$ \\
Methodology & 8 & $17.0 \%$ \\
Modelling method & 1 & $2.1 \%$ \\
Physical models & 18 & $38.3 \%$ \\
Research & 10 & $21.3 \%$ \\
Sum & 47 & $100 \%$ \\
\hline
\end{tabular}

A total of 29 different chemistry contexts for 3D printing were identified. Through content-based analysis, these contexts were classified into three categories: (1) physical molecular models $(n=13),(2)$ physical models $(\mathrm{n}=7)$ and $(3)$ laboratory instrument-related printing $(\mathrm{n}=9)$.

\section{TPACK design strategies (RQ2)}

Here we discuss TPACK design strategies that have been implemented in developing TPACK through 3D printing. First, we present an overview of all the design processes identified. Next, different variations of TPACK processes are explored by reviewing one process at a time. Notably, design processes were not analysed from the ten research articles. The findings related to earlier research are discussed in the next chapter by answering the third research question. Because of this delimitation, the total amount of analysed processes was 37.

Our theory-based content analysis identified three types of design strategies, of which two (processes 1 and 3) were similar to those presented by Koehler et al. (2013) (see Table 4). The majority of the articles ( $\mathrm{n}=$ 18/37) approached the development of 3D printing based TPACK by identifying challenges and possibilities that current pedagogical solutions possess (PCK). After analysing pedagogical needs, 3D printing was used for solving the identified challenges (TCK). The second most common approach for TPACK was developing PCK and TCK simultaneously $(\mathrm{n}=11 / 37)$. A case example of this approach was developing a pedagogical model that integrates 3D printing in teaching as a working method for chemistry learning. In this model students learn chemistry through 3D printing activities. The third approach for TPACK identified in this study was TCK + PCK $(n=8 / 37)$. In this approach the challenges and possibilities were analysed through chemical technology knowledge (e.g. laboratory instruments or 3D printing) and pedagogical solutions were developed for applying this knowledge. We did not find any approaches that would match the description of Koehler et al. (2013) design strategy number 2 (TPK to TPACK). According to the inter-rater reliability test, these results are reliable. We also found that the strength of agreement among two raters was very strong $(\mathrm{k}=0.82)$.

Table 4: TPACK design processes that were identified in this research.

\begin{tabular}{lrr}
\hline TPACK design process & Frequency & Percentage \\
\hline 1. PCK + TCK to TPACK & 18 & $48.6 \%$ \\
2. TPK to TPACK & 0 & $0 \%$ \\
3. PCK/TCK + PCK/TCK/TPK to TPACK & 11 & $29.7 \%$ \\
4. TCK + PCK to TPACK & 8 & $21.6 \%$ \\
Sum & 37 & $99.9 \%$ \\
\hline
\end{tabular}

Inter-rater agreement $=0.82$.

Test was performed using a $30 \%$ sample size $(n=11 / 37)$.

\section{Design process 1: PCK + TCK to TPACK}

PCK-based reasoning was the most used design strategy for TPACK. Through content-based analysis, we identified several PCK-related challenges that authors used for rationalising the use of 3D printing in chemistry 
education. Such arguments include descriptions of challenges in teaching or learning, lack or limitations of current molecular model solutions (e.g. is the model qualitative or based on calculations), or high cost of suitable tangible models. In addition to these challenges, the possibilities that physical models offer for chemistry learning were also mentioned (Table 5). 3D printing was used as a method for designing and manufacturing improved physical models and molecular models (TCK) that could serve as a solution for the abovementioned PCK-based challenges and possibilities. These improvements focused on, for example, the development of more accurate data-based molecular models, or printing models that would be impossible to construct using traditional plastic models. The TPACK goal of this approach was to identify chemistry contexts that would benefit from 3D printing, and develop pedagogical models or use cases for these improved physical models.

Table 5: PCK-based arguments used to justify 3D printing.

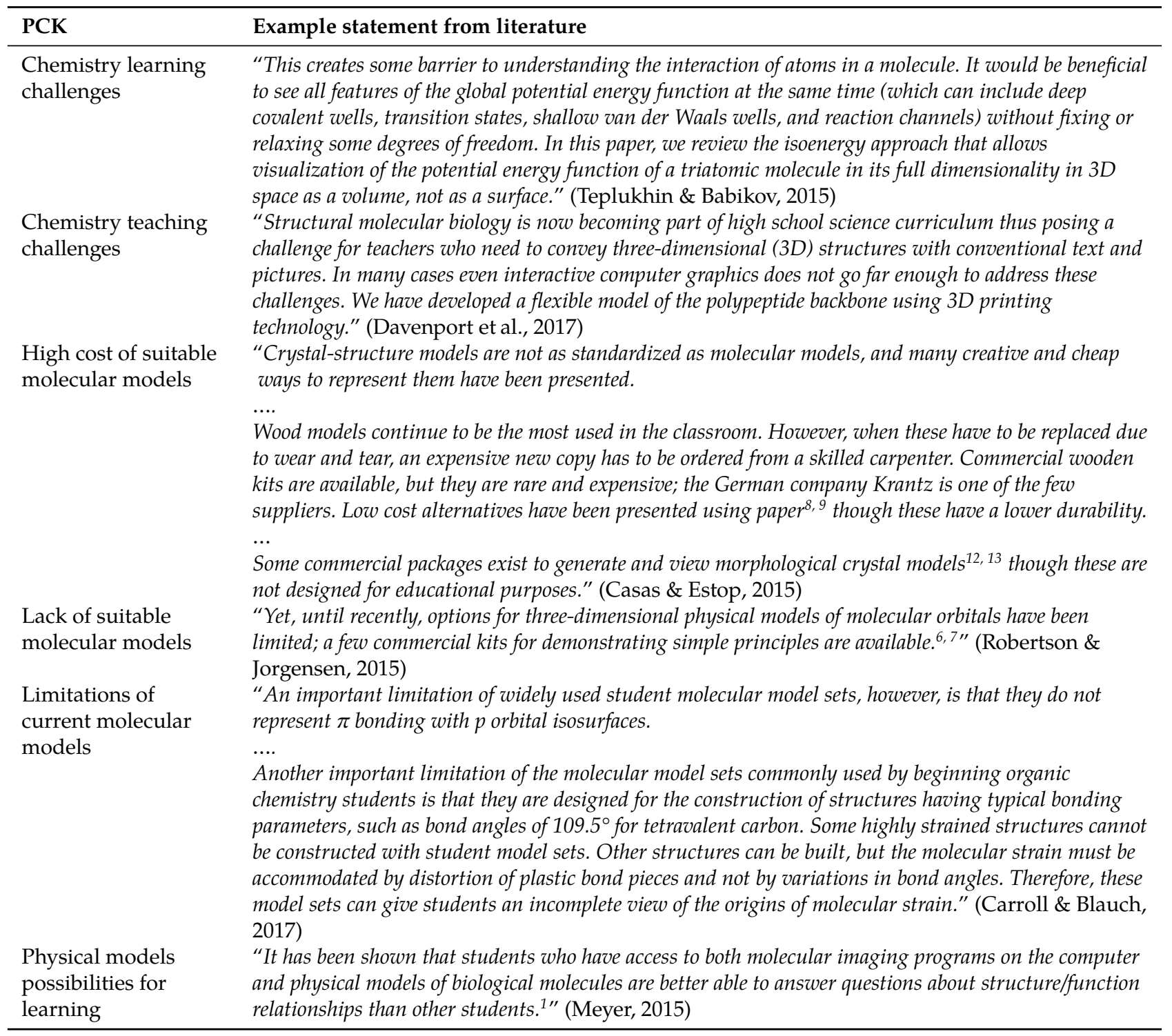

\section{Design process 4: TCK + PCK to TPACK}

All articles in which the authors rationalised 3D printing through TCK-based arguments were classified into this category. These arguments include challenges in current solutions (e.g. quality of models), processes (e.g. high cost, difficulties in the process, or lack of files in the databases), or chemistry knowledge about the possibility to customise laboratory instruments (technology) (Table 6). From a TPACK point of view, 3D printing was used as a method for manufacturing parts for instrument customisation, or the design was focused on developing $3 \mathrm{D}$ printing processes that are more suitable for educational purposes. 
Table 6: TCK-based arguments justifying 3D printing.

\begin{tabular}{|c|c|}
\hline TCK & Example statement from literature \\
\hline $\begin{array}{l}\text { Difficulties in current } \\
\text { printing processes }\end{array}$ & $\begin{array}{l}\text { "The recent development of 3D printing technology has allowed a much wider variety of molecules to be } \\
\text { created for teaching but is not simple to do. Creating the files needed to print molecular structures is } \\
\text { often technically difficult and requires the use of multiple software programs, which are not always } \\
\text { user-friendly. Not all educators or students have the resources or technical skill to create such files and so } \\
\text { are put off trying to use 3D printing in the classroom. Here we demonstrate a simple method to easily } \\
\text { generate the files needed for the 3D printing of almost any molecule using the National Institutes of } \\
\text { Health Print Exchange server (or simple alternatives)." (Jones \& Spencer, 2018) }\end{array}$ \\
\hline $\begin{array}{l}\text { Challenges in data } \\
\text { conversion }\end{array}$ & $\begin{array}{l}\text { "Three-dimensional (3D) printed crystal structures are useful for chemistry teaching and research. } \\
\text { Current manual methods of converting crystal structures into 3D printable files are time-consuming } \\
\text { and tedious. To overcome this limitation, we developed a programmatic method that allows for facile } \\
\text { conversion of thousands of crystal structures directly into 3D printable files." (Scalfani et al., 2016) }\end{array}$ \\
\hline $\begin{array}{l}\text { High cost of } \\
\text { laboratory } \\
\text { instrument parts }\end{array}$ & $\begin{array}{l}\text { "This paper proposes an in-house manufactured } A g / A g C l \text { reference electrode that uses some 3Dprinted } \\
\text { components in the fabrication process. This electrode is cheap to manufacture ( } \$ 5 \text { vs. } \$ 60-100 \mathrm{CAD} \text { for } \\
\text { the commercial reference electrode), and the design can be quickly altered due to the } 3 D \text { printer's } \\
\text { capabilities in rapidly printing new electrode shapes to suit different analysts' needs." (Schmidt, King, } \\
\text { \& Kariuki, 2018) }\end{array}$ \\
\hline $\begin{array}{l}\text { Possibilities for } \\
\text { laboratory } \\
\text { instrument } \\
\text { customisation }\end{array}$ & $\begin{array}{l}\text { "However, the technology reported here is unique in that the measurement device is engineered to allow } \\
\text { direct quantitation of the free ligand with the use of a plate reader, shown in Figure } 1 \text {. The direct } \\
\text { quantitation feature of the device allows the typical time-consuming experiment (approximately } 14 \mathrm{~h} \text { ) to } \\
\text { be set up in a single } 1 \text { h time period and left unattended until the next day." (Pinger, Castiaux, Speed, } \\
\text { \& Spence, 2018) }\end{array}$ \\
\hline $\begin{array}{l}\text { Quality of currently } \\
\text { printed 3D models }\end{array}$ & $\begin{array}{l}\text { "However, printing complex ball-and-stick molecular structures faces distinct challenges, including the } \\
\text { need for support structures that increase with molecular complexity. MolPrint3D is a software add-on } \\
\text { for the Blender 3D modeling package that enhances the printability of ball-and-stick molecular models } \\
\text { by allowing the user to selectively split molecules into fragments. MolPrint3D adds pins to the bond and } \\
\text { holes in the atom at selected junction points to allow the fragments to be printed independently and } \\
\text { assembled. This approach significantly minimizes the number of support structures needed and enables } \\
\text { the construction of large macromolecular structures as ball-and-stick models." (Paukstelis, 2018) }\end{array}$ \\
\hline
\end{tabular}

The majority of the printing methodology articles were assigned to this category. Many evaluated the existing technologies and designed novel technically easy printing processes for all printer types, including low-cost printers. Rossi, Benaglia, Brenna, Porta, and Orlandi (2015) developed a simple procedure for converting protein data bank files into stereolithography with accurate geometry via the Virtual Molecular Dynamic software. Jones and Spencer (2018) describe how the National Institutes of Health 3D Print Exchange website can be used to make the 3D printing process less technical. The service allows the user to upload, edit, and share 3D files that are not ready for printing, and download them as 3D printable files - even when users do not have previous experience in 3D printing. Their objective was to develop a printing process that does not require the use of multiple software programmes, and to encourage teachers and students with low technological skills to use 3D printing.

Some articles describe new software that have been developed for supporting 3D printing. Scalfani et al. (2016) introduced a Jmol script that enables conversion of crystal structures into 3D printable files. Paukstelis (2018) developed MolPrint3D add on for the Blender software that allows splitting molecules into smaller fragments. MolPrint3D adds pins and holes between fragments for assembling. These junction points reduce the need for support structures, which enables printing of even large macromolecular structures as ball-and-stick models. The focus of this research was to improve the quality of currently printed molecular models.

\section{Design process 3: PCK/TCK + PCK/TCK/TPK to TPACK}

This was the most comprehensive TPACK development category, in which we classified all articles that described activities for supporting students' engagement. Articles placed in this category approached TPACK design through PCK or TCK arguments, but they differ from the previous categories because students have an active role in 3D printing. Students will learn chemistry through 3D printing, and vice versa. The central TPACK objective of this category was to develop pedagogical models for integrating 3D printing in chemistry education. For example, Fedick, Schrader, Ayrton, Pulliam, and Cooks (2019) integrated student centered 3D printing activities in learning process analytical technologies (PAT); Dean, Ewan, and McIndoe (2016) developed a new molecular modelling method using hand-held 3D printing pens; and Kosenkov, Shaw, Zuczek, and 
Kholod (2016) developed a project-based learning approach for learning chemistry through novel technologies (Table 7).

Table 7: TPACK strategies where students have an active role in printing.

\begin{tabular}{|c|c|}
\hline TPACK & Example statement from literature \\
\hline $\begin{array}{l}\text { Developing contexts for } \\
\text { integrating instrument } \\
\text { customisation in chemistry } \\
\text { education }\end{array}$ & $\begin{array}{l}\text { "The first learning objective of this laboratory exercise was for students to gain a better } \\
\text { understanding of how PAT can provide real-time information on the course of a chemical } \\
\text { process. An associated objective was to show how the specific measurements are made and } \\
\text { what instrumental and molecular properties determine their success as judged by dynamic } \\
\text { range and duty cycle. The second major learning objective was that students recognize how } \\
\text { rapid prototyping can enable the development of new scientific procedures and innovation } \\
\text { as seen in addressing the rate-and quality-limiting process steps through customization of } \\
\text { analytical instrumentation. Both pedagogical targets were combined with the mission of } \\
\text { bringing cutting-edge research to the teaching laboratory so that students are better } \\
\text { prepared for future developments in chemical analysis." (Fedick et al., 2019) }\end{array}$ \\
\hline $\begin{array}{l}\text { Developing a new modelling } \\
\text { method for chemistry education }\end{array}$ & $\begin{array}{l}\text { "Applying this technology in the teaching of molecular geometry is potentially a valuable } \\
\text { way to enhance student understanding of molecular structure by adding a third dimension } \\
\text { to a student's ability to draw molecules." (Dean et al., 2016) }\end{array}$ \\
\hline $\begin{array}{l}\text { Developing pedagogical models } \\
\text { how to engage students via } 3 \mathrm{D} \\
\text { printing }\end{array}$ & $\begin{array}{l}\text { "Our goal is to develop a project-based approach to teaching laboratory courses and } \\
\text { integrate research projects into the curriculum. It has been shown that undergraduate } \\
\text { research serves as a powerful teaching and curriculum development tool in addition to } \\
\text { advancement of a faculty research program. The present experiment is aimed to bring } \\
\text { novel technologies into the undergraduate laboratory without oversimplifying or hiding } \\
\text { chemical processes behind the technological advancements." (Kosenkov et al., 2016) }\end{array}$ \\
\hline
\end{tabular}

\section{D printing in chemistry education research (RQ3)}

The research articles analysed in our study included some empirical section focusing on chemistry educational research, except one article that focused on measuring ultrafine particles (UFPs) and volatile organic compounds (VOCs) emitted from 3D printing processes (Bharti \& Singh, 2017). The quality of research, however, was not evaluated. Seven of ten research articles discussed topic-specific learning barriers and alternative concepts in theoretical framework. 3D printing was used for producing instructional materials that could support challenges reported in earlier research. Research settings were designed for gathering students' perceptions on learning via physical models (De Cataldo, Griffith, \& Fogarty, 2018; Dean, Ewan, Braden, \& McIndoe, 2019; Hall et al., 2017; Smiar \& Mendez, 2016) or measuring their learning effects (Babilonia-Rosa, Kuo, \& Oliver-Hoyo, 2018; Cooper \& Oliver-Hoyo, 2017; Wuttisela, 2017). Fourches and Feducia (2019) analysed students' perceptions towards 3D printing as a work method. In addition to these, Wedler et al. (2012) developed 3D printing supported chemistry learning methods for blind and visually impaired students, and probed their perceptions towards a developed learning method (see Table 8).

Three articles concentrated fully on research. Babilonia-Rosa et al. (2018) used printed physical models for probing knowledge integration (integrating new ideas to existing cognitive structure) in biochemistry. Using physical models as instructional materials and drawings as a working method, their research - conducted in an introductory biochemistry course for nonmajors $(n=53)$ - produced new knowledge on the mechanisms of knowledge integration. Cooper and Oliver-Hoyo (2017) also worked in an introductory level biochemistry course $(n=131)$. They designed and printed physical models that visualised electrostatics and noncovalent interactions, and their effect on macromolecular structures. They found that the use of physical tangible models can reduce the barriers of understanding and help focus on the important concepts that cause the properties. Wuttisela (2017) developed an assessment tool via 3D printing for measuring pharmacy students' $(n=29)$ understanding of the valence shell electron pair repulsion theory.

Four articles were partly research articles. They addressed the printing process and included a small case study on perceptions or effect on learning. Smiar and Mendez (2016) printed interactive physical molecular models (e.g. hybridisation) and atom models which were well received by students $(n=26)$ in a higher education introductory chemistry course. De Cataldo et al. (2018) also worked with hybridisation with introductory level chemistry students. According to their survey, students $(n=34)$ experienced that physical models supported their understanding of atomic and hybrid orbitals. Hall et al. (2017) evaluated pharmacy students' $(\mathrm{n}=24)$ perceptions and educational benefits of 3D printed molecular models in learning drug receptor and enzyme interactions. They reported that over $90 \%$ of the pharmacy students found that the physical models improved their engaging and learning outcomes. Fourches and Feducia (2019) studied if 3D printing is a suitable work 
method for student-centred activities. They reported that students enjoyed learning organic chemistry through $3 \mathrm{D}$ printing and it supported their engagement to the course.

Table 8: Overview of 3D printing research in chemistry education.

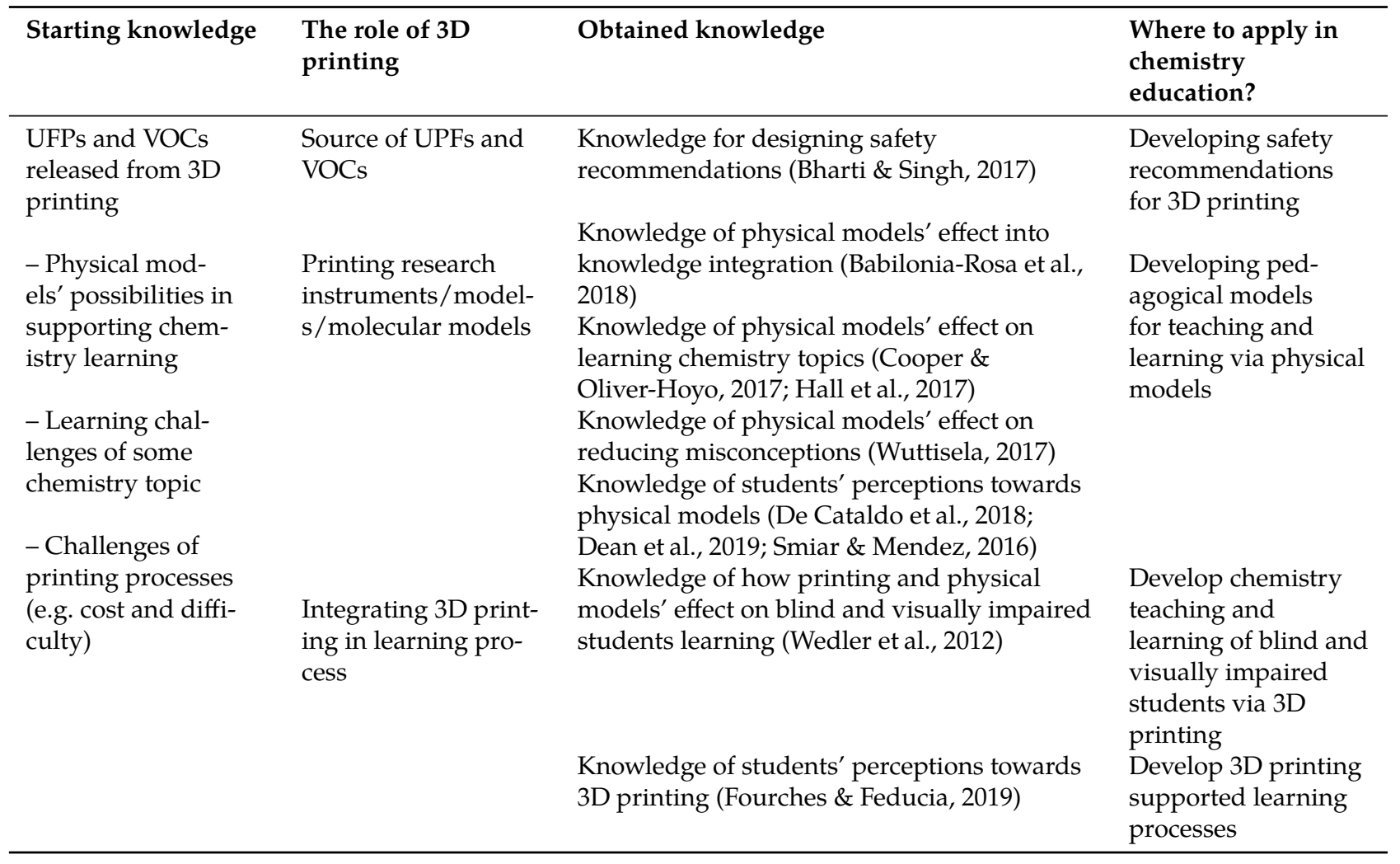

Safety issues related to 3D printing have received little attention in earlier publications. Almost all analysed articles with hands-on activities included some short safety description, but only one article addressed the topic of safety on a comprehensive level. According to Bharti and Singh (2017), there are significant 3D printingrelated safety issues to consider. For example, the two most commonly printed polymers are polylactic acid and acrylonitrile butadiene styrene. These polymers melt during the printing process, which emits particles of UPFs less than $100 \mathrm{~nm}$ wide, VOCs and some other potentially carcinogenic compounds like aldehydes and phthalates (Figure 3) (Azimi, Zhao, Pouzet, Crain, \& Stephens, 2016; Kim et al., 2015).<smiles>C=C(OC(=O)C(=C)OC(=O)C(C)O)C(=O)O</smiles>

PLA

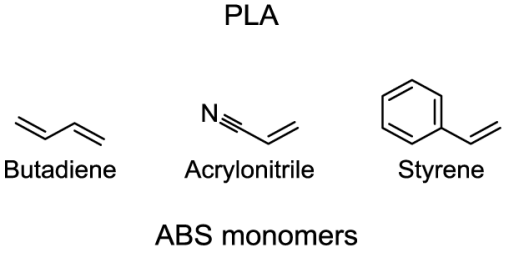

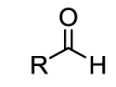

Aldehydes

VOCs
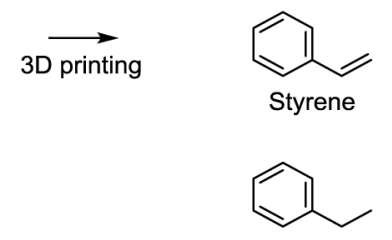

Ethylbenzene
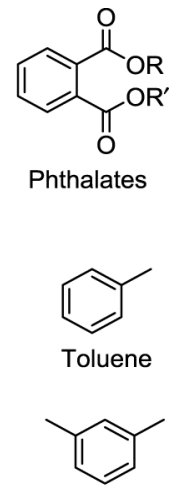

m-xylene

Figure 3: The most commonly used polymers (PLA and ABS) and the compounds emitted during 3D printing processes (Azimi et al., 2016; Kim et al., 2015).

The emission rates of UFPs, VOCs and other compounds have been analysed in a few studies. Kim et al. (2015) found that ABS filaments have higher UPF and VOC emissions than PLA filaments. Azimi et al. (2016) measured the concentration of emissions from multiple commercially available filament desktop printers, and observed a significant increase in UPFs and VOCs (especially styrene, which is classified as a possible carcinogen for humans) in the printing space. Bharti and Singh (2017) measured the number of UPFs in libraries and 
makerspaces. Importantly, they observed a significant increase in UPF levels even $24 \mathrm{~h}$ after the printers had been shut down. Because of this, 3D printers should only be used in a well-ventilated space or a fume hood. The authors emphasise that avoiding inhalation of UPFs and VOCs must be taken into account during 3D printing, and they have suggested pragmatic safety instructions that are well applicable in chemistry education (Bharti \& Singh, 2017).

\section{Conclusions}

3D printing is a rapidly growing industry (Hart, 2017a, Hart), however it still remains a niche topic in chemistry education. Only 47 peer-reviewed articles have been published about 3D printing in chemistry education, only ten of which are research papers. Most of these earlier studies have focused on finding relevant chemistry topics that would benefit from 3D printing (see Table 9). Because of this, the most common way to design TPACK was to analyse PCK-based chemistry educational challenges (Koehler et al., 2013) that could be solved via designing and printing improved physical models (TCK). These improvements were rationalised, for example, through the need for more accurate models or lack of available solutions. For example, 3D printing enables data-based model design (e.g. Carroll \& Blauch, 2017) and printing complex structures that are not possible to construct with traditional plastic models (e.g. Casas \& Estop, 2015; Lolur \& Dawes, 2014).

Table 9: Classification of 3D printing contexts in chemistry education.

\begin{tabular}{llll}
\hline$\#$ & Physical molecular models & Physical models & Laboratory instruments \\
\hline 1 & Crystal structures & Bohr model & Ag/AgCl reference electrodes \\
2 & Hybrid orbitals & Diffraction grating models & Centrifugal pump \\
3 & Hydrogenic orbitals & Energy surface model & Colorimeter \\
4 & Molecular orbitals & Periodic table trend models & Fluorometer \\
5 & Multicolor molecular models & Potential energy function model & Four-point probe station \\
6 & Nanostructures & Potential energy surface model & Mesoreactors \\
7 & p Orbital iso-surfaces & Reaction surface model & Optical hardware for \\
& & & spectrophotometer \\
8 & Protein folding model & & Plate reader \\
9 & Protein macromolecules & & Sample holder \\
10 & Scalable molecular model & & \\
11 & Symmetry and point group models & & \\
12 & Valence shell electron pair & & \\
& repulsion (VSEPR) model & & \\
13 & $\pi$-Bonding model &
\end{tabular}

Another major subject-specific approach was to first analyse the chemistry technological challenges (TCK) and then use 3D printing to solve them, with some educational objective (PCK). This approach was not present in Koehler et al. (2013) TPACK design strategy classification. One possible reason for this could be that their data did not include any subject-specific TPACK development projects.

Only 11 articles described pedagogical models where students had an active role in 3D printing. Twentynine of the studied articles reported different PCK- or TCK-based challenges for which solutions were found through 3D printing. These articles offer a high pedagogical value from a chemistry context (TCK) perspective, but the contributions for comprehensive development of TPACK are quite limited (Koehler \& Mishra 2005; 2009; Koehler et al., 2013; Mishra \& Koehler, 2006). Hence, due to this clear knowledge gap, there is a great need for developing student centred 3D printing activities for chemistry education. This result is in line with earlier 3D printing studies carried out from a general educational perspective. For example, it has been found that 3D printing is often used to support traditional teaching methods (see Nemorin \& Selwyn, 2017).

In conclusion, exploiting the potential of 3D printing in chemistry education could be much more holistic. Suitable chemistry contexts for 3D printing are already well known, as researchers have been mapping these out for almost a decade. In chemistry education research, however, the use of 3D printing has been rare. Thus far, it has mainly been used as a tool for manufacturing research instruments for studying students' perceptions towards physical models or their effect on learning (e.g. Wuttisela, 2017). There is some evidence that 3D printing is suitable for student-centred activities for supporting the engagement in studies (Fourches \& Feducia, 2019), but in order to develop more versatile and holistic models for integrating 3D printing in chemistry education, it would be crucial to study whether 3D printing is a relevant work method for future chemistry teachers'. Relevance should be analysed from several perspectives, for example, possibilities for learning, en- 
gagement, self-confidence, professional development etc. and also its societal relevance (see Stuckey, Hofstein, Mamlok-Naaman, \& Eilks, 2013). Based on this knowledge, it would be easier to design research-based 3D printing learning environments relevant for chemistry education. And it is important to remember that when new pedagogical models and learning environments are designed, safety details must be taken account for because of the large amount of potentially carcinogenic UFPs and VOCs that 3D printing releases (Bharti \& Singh, 2017).

\section{Appendix 1}

\section{Classification of analysed 3D printing articles}

\section{Laboratory (10)}

1. Ballesteros, M. A., Daza, M. A., Valdés, J. P., Ratkovich, N., \& Reyes, L. H. (2019). Applying PBL methodologies to the chemical engineering courses: Unit operations and modeling and simulation, using a joint course project. Education for Chemical Engineers. https:// doi.org/10.1016/j.ece.2019.01.005.

2. Davis, E. J., Jones, M., Thiel, D. A., \& Pauls, S. (2018). Using open-source, 3D printable optical hardware to enhance student learning in the instrumental analysis laboratory. Journal of Chemical Education, 95(4), 672677. https://doi.org/10.1021/acs.jchemed.7b00480.

3. Fedick, P. W., Schrader, R. L., Ayrton, S. T., Pulliam, C. J., \& Cooks, R. G. (2019). Process analytical technology for online monitoring of organic reactions by mass spectrometry and UV-Vis spectroscopy. Journal of Chemical Education, 96(1), 124-131. https://doi.org/10.1021/acs.jchemed.8b00725.

4. Kosenkov, D., Shaw, J., Zuczek, J., \& Kholod, Y. (2016). Transient-Absorption spectroscopy of Cis-Trans isomerization of N,N-dimethyl-4,4'-azodianiline with 3D-printed temperature-controlled sample holder. Journal of Chemical Education, 93(7), 1299-1304. https://doi.org/10.1021/acs.jchemed.6b00121.

5. Lu, Y., Santino, L. M., Acharya, S., Anandarajah, H., \& D'Arcy, J. M. (2017). Studying electrical conductivity using a 3D printed four-point probe station. Journal of Chemical Education, 94(7), 950-955. https://doi.org/10.1021/acs.jchemed.7b00119.

6. Pinger, C. W., Castiaux, A., Speed, S., \& Spence, D. M. (2018). Plate reader compatible 3Dprinted device for teaching equilibrium dialysis binding assays. Journal of Chemical Education. https://doi.org/10.1021/acs.jchemed.8b00215.

7. Porter, L. A., Chapman, C. A., \& Alaniz, J. A. (2017). Simple and inexpensive 3D printed filter fluorometer designs: User-friendly instrument models for laboratory learning and outreach activities. Journal of Chemical Education, 94(1), 105-111. https://doi.org/10.1021/acs.jchemed.6b00495.

8. Porter, L. A., Washer, B. M., Hakim, M. H., \& Dallinger, R. F. (2016). User-friendly 3D printed colorimeter models for student exploration of instrument design and performance. Journal of Chemical Education, 93(7), 1305-1309. https://doi.org/10.1021/acs.jchemed.6b00041.

9. Schmidt, B., King, D., \& Kariuki, J. (2018). Designing and using 3D-printed components that allow students to fabricate low-cost, adaptable, disposable, and reliable $\mathrm{Ag} / \mathrm{AgCl}$ reference electrodes. Journal of Chemical Education. https://doi.org/10.1021/acs.jchemed.8b00512.

10. Tabassum, T., Iloska, M., Scuereb, D., Taira, N., Jin, C., Zaitsev, V., ... Kim, T. (2018). Development and application of 3D printed mesoreactors in chemical engineering education. Journal of Chemical Education, 95(5), 783-790. https://doi.org/10.1021/acs.jchemed.7b00663.

\section{Methodology (8)}

1. Jones, O. A. H., \& Spencer, M. J. S. (2018). A simplified method for the 3D printing of molecular models for chemical education. Journal of Chemical Education, 95(1), 88-96. https://doi.org/10.1021/acs.jchemed.7b00533. 
2. Muskin, J., Ragusa, M., \& Gelsthorpe, T. (2010). Three-dimensional printing using a photoinitiated polymer. Journal of Chemical Education, 87(5), 512-514. https://doi.org/10.1021/ed800170t.

3. Paukstelis, P. J. (2018). MolPrint3D: Enhanced 3D printing of ball-and-stick molecular models. Journal of Chemical Education, 95(1), 169-172. https://doi.org/10.1021/acs.jchemed.7b00549.

4. Penny, M. R., Cao, Z. J., Patel, B., Sil dos Santos, B., Asquith, C. R. M., Szulc, B. R., ... Hilton, S. T. (2017). Three-dimensional printing of a scalable molecular model and orbital kit for organic chemistry teaching and learning. Journal of Chemical Education, 94(9), 1265-1271. https://doi.org/10.1021/acs.jchemed.6b00953.

5. Rossi, S., Benaglia, M., Brenna, D., Porta, R., \& Orlandi, M. (2015). Three dimensional (3D) printing: A straightforward, user-friendly protocol to convert virtual chemical models to real-life objects. Journal of Chemical Education, 92(8), 1398-1401. https:/ / doi.org/10.1021/acs.jchemed.5b00168.

6. Scalfani, V. F., Williams, A. J., Tkachenko, V., Karapetyan, K., Pshenichnov, A., Hanson, R. M., ...Bara, J. E. (2016). Programmatic conversion of crystal structures into 3D printable files using Jmol. Journal of Cheminformatics, 8, 66. https://doi.org/10.1186/s13321-016-0181-z.

7. Van Wieren, K., Tailor, H. N., Scalfani, V. F., \& Merbouh, N. (2017). Rapid access to multicolor three-dimensional printed chemistry and biochemistry models using visualization and three-dimensional printing software programs. Journal of Chemical Education, 94(7), 964-969. https://doi.org/10.1021/acs.jchemed.6b00602.

8. Wood, P. A., Sarjeant, A. A., Bruno, I. J., Macrae, C. F., Maynard-Casely, H. E., \& Towler, M. (2017). The next dimension of structural science communication: Simple 3D printing directly from a crystal structure. CrystEngComm, 19(4), 690-698. https://doi.org/10.1039/C6CE02412B

\section{Modelling method (1)}

1. Dean, N. L., Ewan, C., \& McIndoe, J. S. (2016). Applying hand-held 3D printing technology to the teaching of VSEPR theory. Journal of Chemical Education, 93(9), 1660-1662. https://doi.org/10.1021/acs.jchemed.6b00186.

\section{Printing physical models (18)}

1. Carroll, F. A., \& Blauch, D. N. (2017). 3D printing of molecular models with calculated geometries and $\mathrm{p}$ orbital isosurfaces. Journal of Chemical Education, 94(7), 886-891. https://doi.org/10.1021/acs.jchemed.6b00933.

2. Carroll, F. A., \& Blauch, D. N. (2018). Using the force: Three-dimensional printing a $\pi$-bonding model with embedded magnets. Journal of Chemical Education. https://doi.org/10.1021/acs.jchemed.7b00987.

3. Casas, L., \& Estop, E. (2015). Virtual and printed 3D models for teaching crystal symmetry and point groups. Journal of Chemical Education, 92(8), 1338-1343. https://doi.org/10.1021/acs.jchemed.5b00147.

4. Davenport, J., Pique, M., Getzoff, E., Huntoon, J., Gardner, A., \& Olson, A. (2017). A selfassisting protein folding model for teaching structural molecular biology. Structure, 25(4), 671-678. https://doi.org/10.1016/j.str.2017.03.001.

5. Fisher, N. B., Charbonneau, J. C., \& Hurst, S. K. (2016). Rapid creation of three-dimensional, tactile models from crystallographic data [Research article]. https:/ /doi.org/10.1155/2016/3054573.

6. Gražulis, S., Sarjeant, A. A., Moeck, P., Stone-Sundberg, J., Snyder, T. J., Kaminsky, W., ...Kantardjieff, K. A. (2015). Crystallographic education in the 21st century. Journal of Applied Crystallography, 48(6), 1964-1975. https://doi.org/10.1107/S1600576715016830.

7. Griffith, K. M., e Cataldo, R., \& Fogarty, K. H. (2016). Do-it-yourself: 3D models of hydrogenic orbitals through 3D printing. Journal of Chemical Education, 93(9), 1586-1590. https://doi.org/10.1021/acs.jchemed.6b00293. 
8. Higman, C. S., Situ, H., Blacklin, P., \& Hein, J. E. (2017). Hands-on data analysis: Using 3D printing to visualize reaction progress surfaces. Journal of Chemical Education, 94(9), 1367-1371. https://doi.org/10.1021/acs.jchemed.7b00314.

9. Kaliakin, D. S., Zaari, R. R., \& Varganov, S. A. (2015). 3D printed potential and free energy surfaces for teaching fundamental concepts in physical chemistry. Journal of Chemical Education, 92(12), 2106-2112. https://doi.org/10.1021/acs.jchemed.5b00409.

10. LeSuer, R. J. (2019). Incorporating tactile learning into periodic trend analysis using three-dimensional printing. Journal of Chemical Education, 96(2), 285-290. https://doi.org/10.1021/acs.jchemed.8b00592.

11. Lolur, P., \& Dawes, R. (2014). 3D printing of molecular potential energy surface models. Journal of Chemical Education, 91(8), 1181-1184. https://doi.org/10.1021/ed500199m.

12. Meyer, S. C. (2015, October 9). 3D printing of protein models in an undergraduate laboratory: Leucine zippers [research-article]. https://doi.org/10.1021/acs.jchemed.5b00207.

13. Piunno, P. A. E. (2017). Teaching the operating principles of a diffraction grating using a 3D-printable demonstration kit. Journal of Chemical Education, 94(5), 615-620. https://doi.org/10.1021/acs.jchemed.6b00906.

14. Robertson, M. J., \& Jorgensen, W. L. (2015). Illustrating concepts in physical organic chemistry with 3D printed orbitals. Journal of Chemical Education, 92(12), 2113-2116. https://doi.org/10.1021/acs.jchemed.5b00682.

15. Rodenbough, P. P., Vanti, W. B., \& Chan, S.-W. (2015). 3D-printing crystallographic unit cells for learning materials science and engineering. Journal of Chemical Education, 92(11), 1960-1962. https://doi.org/10.1021/acs.jchemed.5b00597.

16. Scalfani, V. F., \& Vaid, T. P. (2014). 3D printed molecules and extended solid models for teaching symmetry and point groups. Journal of Chemical Education, 91(8), 1174-1180. https://doi.org/10.1021/ed400887t.

17. Scalfani, V. F., Turner, C. H., Rupar, P. A., Jenkins, A. H., \& Bara, J. E. (2015). 3D printed block copolymer nanostructures. Journal of Chemical Education, 92(11), 1866-1870. https://doi.org/10.1021/acs.jchemed.5b00375.

18. Teplukhin, A., \& Babikov, D. (2015). Visualization of potential energy function using an isoenergy approach and 3D prototyping. Journal of Chemical Education, 92(2), 305-309. https://doi.org/10.1021/ed500683g.

\section{Research (10)}

1. Babilonia-Rosa, M. A., Kuo, K. H., \& Oliver-Hoyo, M. T. (2018). Using 3D printed physical models to monitor knowledge integration in biochemistry. Chemistry Education Research and Practice, 19(4), 1199-1215. https://doi.org/10.1039/C8RP00075A.

2. Bharti, N., \& Singh, S. (2017). Three-dimensional (3D) printers in libraries: Perspective and preliminary safety analysis. Journal of Chemical Education, 94(7), 879-885. https://doi.org/10.1021/acs.jchemed.6b00745.

3. Cooper, A. K., \& Oliver-Hoyo, M. T. (2017). Creating 3D physical models to probe student understanding of macromolecular structure. Biochemistry and Molecular Biology Education, 45(6), 491-500. https://doi.org/10.1002/bmb.21076.

4. Dean, N. L., Ewan, C., Braden, D., \& McIndoe, J. S. (2019). Open-source laser-cut-model kits for the teaching of molecular geometry. Journal of Chemical Education. https://doi.org/10.1021/acs.jchemed.8b00553.

5. De Cataldo, R., Griffith, K. M., \& Fogarty, K. H. (2018). Hands-on hybridization: 3D-printed models of hybrid orbitals. Journal of Chemical Education, 95(9), 1601-1606. https://doi.org/10.1021/acs.jchemed.8b00078.

6. Fourches, D., \& Feducia, J. (2019). Student-guided three-dimensional printing activity in large lecture courses: A practical guideline. Journal of Chemical Education, 96(2), 291-295. https://doi.org/10.1021/acs.jchemed.8b00346.

7. Hall, S., Grant, G., Arora, D., Karaksha, A., McFarland, A., Lohning, A., \& Anoopkumar-Dukie, S. (2017). A pilot study assessing the value of 3D printed molecular modelling tools for pharmacy student education. Currents in Pharmacy Teaching and Learning, 9(4), 723-728. https://doi.org/10.1016/j.cpt1.2017.03.029. 
8. Smiar, K., \& Mendez, J. D. (2016). Creating and using interactive, 3D-printed models to improve student comprehension of the Bohr model of the atom, bond polarity, and hybridization. Journal of Chemical Education, 93(9), 1591-1594. https://doi.org/10.1021/acs.jchemed.6b00297.

9. Wedler, H. B., Cohen, S. R., Davis, R. L., Harrison, J. G., Siebert, M. R., Willenbring, D., ...Tantillo, D. J. (2012). Applied computational chemistry for the blind and visually impaired. Journal of Chemical Education, 89(11), 1400-1404. https://doi.org/10.1021/ed3000364.

10. Wuttisela, K. (2017). Authentic assessment tool for the measurement of students' understanding of the valence shell electron pair repulsion theory. Universal Journal of Educational Research, 5(9), 1549-1553. https://doi.org/10.13189/ujer.2017.050912.

\section{References}

Andraos, J., \& Dicks, A. P. (2012). Green chemistry teaching in higher education: A review of effective practices. Chemistry Education Research and Practice, 13(2), 69-79.

Azimi, P., Zhao, D., Pouzet, C., Crain, N. E., \& Stephens, B. (2016). Emissions of ultrafine particles and volatile organic compounds from commercially available desktop three-dimensional printers with multiple filaments. Environmental Science \& Technology, 50(3), 1260-1268.

Babilonia-Rosa, M. A., Kuo, K. H., \& Oliver-Hoyo, M. T. (2018). Using 3D printed physical models to monitor knowledge integration in biochemistry. Chemistry Education Research and Practice, 19(4), 1199-1215.

Bharti, N., \& Singh, S. (2017). Three-dimensional (3D) printers in libraries: Perspective and preliminary safety analysis. Journal ofChemical Education, 94(7), 879-885.

Blonder, R., Jonatan, M., Bar-Dov, Z., Benny, N., Rap, S., \& Sakhnini, S. (2013). Can you tube it? Providing chemistry teachers with technological tools and enhancing their self-efficacy beliefs. Chemistry Education Research and Practice, 14(3), 269-285.

Blonder, R., \& Rap, S. (2017). I like Facebook: Exploring Israeli high school chemistry teachers' TPACK and self-efficacy beliefs. Education and Information Technologies, 22(2), 697-724.

Çalik, M., Özsevgeç, T., Ebenezer, J., Artun, H., \& Küçük, Z. (2014). Effects of “Environmental Chemistry” elective course via technologyembedded scientific inquiry model on some variables. Journal of Science Education and Technology, 23(3), 412-430.

Carroll, F. A., \& Blauch, D. N. (2017). 3D printing of molecular models with calculated geometries and p orbital isosurfaces. Journal of Chemical Education, 94(7), 886-891.

Casas, L., \& Estop, E. (2015). Virtual and printed 3D models for teaching crystal symmetry and point groups. Journal of Chemical Education, 92(8), 1338-1343.

Cetin-Dindar, A., Boz, Y., Sonmez, D. Y., \& Celep, N. D. (2018). Development of pre-service chemistry teachers' technological pedagogical content knowledge. Chemistry Education Research and Practice, 19(1), 167-183.

Cooper, A. K., \& Oliver-Hoyo, M. T. (2017). Creating 3D physical models to probe student understanding of macromolecular structure. Biochemistry and Molecular Biology Education, 45(6), 491-500.

Cox, S. (2008). A conceptual analysis of technological pedagogical content knowledge. Doctoral dissertation, Brigham Young University. Retrieved from http://hdl.lib.byu.edu/1877/etd2552.

Jamie, D. (2018). 3D Printing vs CNC machining: Which is best for prototyping? Retrieved 17 June 2019, from 3Dnatives website: https://www.3dnatives.com/en/3d-printing-vs-cnc-160320184/.

Davenport, J., Pique, M., Getzoff, E., Huntoon, J., Gardner, A., \& Olson, A. (2017). A self-assisting protein folding model for teaching structural molecular biology. Structure, 25(4), 671-678.

Davis, E. J., Jones, M., Thiel, D. A., \& Pauls, S. (2018). Using open-source, 3D printable optical hardware to enhance student learning in the instrumental analysis laboratory. Journal of Chemical Education, 95(4), 672-677.

De Cataldo, R., Griffith, K. M., \& Fogarty, K. H. (2018). Hands-on hybridization: 3D-printed models of hybrid orbitals. Journal ofChemical Education, 95(9), 1601-1606.

Dean, N. L., Ewan, C., \& Mclndoe, J. S. (2016). Applying hand-held 3D printing technology to the teaching of VSEPR theory. Journal ofChemical Education, 93(9), 1660-1662.

Dean, N. L., Ewan, C., Braden, D., \& Mclndoe, J. S. (2019). Open-source laser-cut-model kits for the teaching of molecular geometry. Journal of Chemical Education, 96, 495-499.

Fedick, P. W., Schrader, R. L., Ayrton, S. T., Pulliam, C. J., \& Cooks, R. G. (2019). Process analytical technology for online monitoring of organic reactions by mass spectrometry and UV-vis spectroscopy. Journal ofChemical Education, 96(1), 124-131.

Fourches, D., \& Feducia, J. (2019). Student-guided three-dimensional printing activity in large lecture courses: A practical guideline. Journal of Chemical Education, 96(2), 291-295.

Graham, C. R. (2011). Theoretical considerations for understanding technological pedagogical content knowledge (TPACK). Computers $\mathcal{E}$ Education, 57(3), 1953-1960.

Hall, S., Grant, G., Arora, D., Karaksha, A., McFarland, A., Lohning, A., \& Anoopkumar-Dukie, S. (2017). A pilot study assessing the value of 3D printed molecular modelling tools for pharmacy student education. Currents in Pharmacy Teaching and Learning, 9(4), 723-728.

Hart, W. (2017a). Overcoming the additive manufacturing skill gap pt. I. Retrieved 22 October 2018, from 3D Printing Industry website: https://3dprintingindustry.com/news/overcoming-additive-manufacturing-skill-gap-pt-117026/.

Hart, W. (2017b). Overcoming the Additive Manufacturing skill gap pt. 2: Inspiring the next generation. Retrieved 22 October 2018, from 3D Printing Industry website: https://3dprintingindustry.com/news/overcoming-additive-manufacturing-skill-gap-pt-2-inspiring-nextgeneration-117977/. 
Helppolainen, S., \& Aksela, M. (2015). Science teachers' ICT use from a viewpoint of technological pedagogical content knowledge (TPCK). LUMAT, 3(6), 783-799.

Jones, O. A. H., \& Spencer, M. J. S. (2018). A simplified method for the 3D printing of molecular models for chemical education. Journal of Chemical Education, 95(1), 88-96.

Khan, S. (2011). New pedagogies on teaching science with computer simulations. Journal of Science Education and Technology, 20(3), 215-232.

Kim, Y., Yoon, C., Ham, S., Park, J., Kim, S., Kwon, O., \& Tsai, P.-J. (2015). Emissions of nanoparticles and gaseous material from 3D printer operation. Environmental Science \& Technology, 49(20), 12044-12053.

Koehler, M., \& Mishra, P. (2005). What happens when teachers design educational technology? The development of technological pedagogical content knowledge. Journal of Educational Computing Research, 32(2), 131-152.

Koehler, M., \& Mishra, P. (2009). What is technological pedagogical content knowledge (TPACK)? Contemporary Issues in Technology and Teacher Education, 9(1), 60-70.

Koehler, M., Mishra, P., \& Cain, W. (2013). What is technological pedagogical content knowledge (TPACK)? Journal of Education, 193(3), 13-19.

Kosenkov, D., Shaw, J., Zuczek, J., \& Kholod, Y. (2016). Transient-absorption spectroscopy of Cis-trans isomerization of N,N-dimethyl-4,4'azodianiline with 3D-printed temperature-controlled sample holder. Journal of Chemical Education, 93(7), 1299-1304.

Krippendorff, K. (2004). Content analysis: An introduction to its methodology (2nd ed.). Thousand Oaks, Calif: Sage.

Litts, B. (2015). Making learning: Makerspaces as learning environments. Doctoral Dissertation, University of Wisconsin-Madison. Retrieved from http://www.informalscience.org/sites/default/files/Litts_2015_Dissertation_Published.pdf.

Lolur, P., \& Dawes, R. (2014). 3D printing of molecular potential energy surface models. Journal of Chemical Education, 91(8), $1181-1184$.

Long, L. (2018). 3D printing is poised to continue outpacing growth of traditional manufacturing. Retrieved 18 October 2018, from engineering.com website: https://www.engineering.com/AdvancedManufacturing/ArticlelD/16873/3D-Printing-Is-Poised-to-ContinueOutpacing-Growth-of-Traditional-Manufacturing.aspx.

McHugh, M. L. (2012). Interrater reliability: The kappa statistic. Biochemia Medica, 22(3), 276-282.

Meyer, S. C. (2015). 3D printing of protein models in an undergraduate laboratory: Leucine zippers [Research-article]. Journal ofChemical Education, 92, 2120-2125.

Mishra, P., \& Koehler, M. J. (2006). Technological pedagogical content knowledge: A framework for teacher knowledge. Teachers College Record, 108(6), 1017-1054.

Nemorin, S., \& Selwyn, N. (2017). Making the best of it? Exploring the realities of 3D printing in school. Research Papers in Education, 32(5), 578595.

Nightingale, A. (2009). A guide to systematic literature reviews. Surgery (Oxford), 27(9), 381-384.

Paukstelis, P. J. (2018). MolPrint3D: Enhanced 3D printing of ball-and-stick molecular models. Journal of Chemical Education, 95(1), 169-172.

Pinger, C. W., Castiaux, A., Speed, S., \& Spence, D. M. (2018). Plate reader compatible 3D-printed device for teaching equilibrium dialysis binding assays. Journal of Chemical Education, 95, 1662-1667.

Rayna, T., \& Striukova, L. (2016). From rapid prototyping to home fabrication: How 3D printing is changing business model innovation. Technological Forecasting and Social Change, 102, 214-224.

Robertson, M. J., \& Jorgensen, W. L. (2015). Illustrating concepts in physical organic chemistry with 3D printed orbitals. Journal ofChemical Education, 92(12), 2113-2116.

Rossi, S., Benaglia, M., Brenna, D., Porta, R., \& Orlandi, M. (2015). Three dimensional (3D) printing: A straightforward, user-friendly protocol to convert virtual chemical models to real-life objects. Journal of Chemical Education, 92(8), 1398-1401.

Scalfani, V. F., Williams, A. J., Tkachenko, V., Karapetyan, K., Pshenichnov, A., Hanson, R. M., Liddie, J. M., \& Bara, J. E. (2016). Programmatic conversion of crystal structures into 3D printable files using Jmol. Journal of Cheminformatics, 8, 66.

Schmidt, B., King, D., \& Kariuki, J. (2018). Designing and using 3D-printed components that allow students to fabricate low-cost, adaptable, disposable, and reliable $\mathrm{Ag} / \mathrm{AgCl}$ reference electrodes. Journal ofChemical Education, 95, 2076-2080.

Shulman, L. S. (1986). Those who understand: Knowledge growth in teaching. Educational Researcher, 15(2), 4-14.

Shulman, L. (1987). Knowledge and teaching: Foundations of the new reform. Harvard Educational Review, 57(1), 1-23.

Smiar, K., \& Mendez, J. D. (2016). Creating and using interactive, 3D-printed models to improve student comprehension of the Bohr model of the atom, bond polarity, and hybridization. Journal of Chemical Education, 93(9), 1591-1594.

Stuckey, M., Hofstein, A., Mamlok-Naaman, R., \& Eilks, I. (2013). The meaning of "relevance" in science education and its implications for the science curriculum. Studies in Science Education, 49(1), 1-34.

Teplukhin, A., \& Babikov, D. (2015). Visualization of potential energy function using an isoenergy approach and 3D prototyping. Journal of Chemical Education, 92(2), 305-309.

TPACK.org. (2018). TPACK | Mendeley. Retrieved 23 October 2018, from Public Group - TPACK - Social Sciences website: https://www.mendeley.com/community/tpack/.

Trust, T., \& Maloy, R. W. (2017). Why 3D print? The $21^{\text {st }}$-century skills students develop while engaging in 3D printing projects. Computers in the Schools, 34(4), 253-266.

Wedler, H. B., Cohen, S. R., Davis, R. L., Harrison, J. G., Siebert, M. R., Willenbring, D., Hamam, C., Shaw, J. T., \& Tantillo, D. J. (2012). Applied computational chemistry for the blind and visually impaired. Journal of Chemical Education, 89(11), 1400-1404.

Willermark, S. (2018). Technological pedagogical and content knowledge: A review of empirical studies published from 2011 to 2016 . Journal of Educational Computing Research, 56(3), 315-343.

Wuttisela, K. (2017). Authentic assessment tool for the measurement of students' understanding of the valence shell electron pair repulsion theory. Universal Journal of Educational Research, 5(9), 1549-1553. 